\title{
A África carioca em lentes européias: corpos, sinais e expressões ${ }^{1}$
}

Eneida Maria Mercadante Sela

UNICAMP

\section{RESUMO}

A proposta deste artigo é examinar as maneiras pelas quais alguns viajantes europeus que estiveram no Rio de Janeiro durante a primeira metade do século XIX diferenciaram os africanos na experiência da escravidão, tratando de um viés temático específico: os registros produzidos pela literatura de viagem oitocentista a respeito de suas belezas físicas, sinais corporais e expressões de cantos e danças. A convergência temática e valorativa desses relatos permite-nos observar a reiteração de certas tópicas que cristalizaram os significados mais comuns atribuídos pelos olhares estrangeiros aos africanismos com que depararam na cidade que continha, à época, a maior população escrava das Américas.

Palavras-chave: Escravos africanos (Rio de Janeiro, século XIX); Viajantes europeus; Africanismos.

\section{ABSTRACT}

The proposal of this article is to investigate the ways some European travellers, who have came to the city of Rio de Janeiro during the first half of the $19^{\text {th }}$ century, registered Africans in the slavery experience. Foreigners who visited Brazilian Court until 1850 faced the biggest African slave population of the Americas, and the set of their literature, which describes such cultural and social counterpose, reveals conceptual reiterations of a whole lot of physical and behavioural characteristics given to Africans in captivity.

Keywords: African slaves (Rio de Janeiro, $19^{\text {th }}$ century); European travellers; Africanisms.

A historiadora Mary Karasch, em seu monumental A vida dos escravos no Rio de Janeiro (1808-1850), ${ }^{2}$ justifica a escolha desse recorte temporal por julgá-lo propício a acompanhar as "transformações da cultura escrava", pois foi quando a escravidão esteve em seu auge: "nem antes de 1808, nem depois de 1850, os escravos dominaram de tal forma a vida na cidade" (p.28). Em 1849, havia aproximadamente 80 mil cativos no Rio, cidade que, durante as 
três décadas anteriores, abrigou a maior população escrava das Américas. Mais importante, porém, do que contabilizar essa multidão no Rio de Janeiro, Karasch nos apresenta, por meio de numerosos cruzamentos de fontes e tabelas, um domínio da população africana, chegando a constituir três quartos do contingente escravo na cidade durante a década de 1830 (p.41).

Essa reconstituição da demografia escrava carioca da primeira metade do século XIX possibilita-nos imaginar mais concretamente em que mundo se moveram os visitantes europeus que lá estiveram nesse período, e por que insistiam em alusões, de múltiplas naturezas, a heranças, hábitos, modos, feições, traços e fisionomias africanas quando descreviam os negros, em letras ou imagens. É patente que a escravidão foi um tema que perpassou a grande maioria dos registros que compõem o heterogêneo conjunto da literatura de viagem sobre o Brasil oitocentista. Entretanto, se nos dedicarmos a uma análise das descrições empreendidas durante as primeiras décadas daquele século, um ingrediente particular pode ser notado: a recorrência de imagens e textos que insistem em marcar as origens africanas dos escravos, das mais diversas formas. Portanto, a obra de Mary Karasch nos demonstra a configuração de uma realidade social fértil para esses registros.

Como se sabe, foi a abertura dos portos de D. João que possibilitou uma verdadeira profusão de estrangeiros que, além da permanência mais prolongada no Rio de Janeiro, empreenderam muitas expedições pelas regiões internas do Brasil. ${ }^{3}$ A cidade era, pois, passagem obrigatória para grande parte dos viajantes oitocentistas, fosse por apenas alguns dias, ou até por muitos anos. Assim a Corte imperial foi, sem dúvida, o laboratório cultural mais completo e diversificado no qual os modos de ver europeus exercitaram interpretações para os modos de ser africanos no cativeiro.

\section{UMA VITRINE DE “MIL NUANÇAS”}

Quando um viajante pisa no Rio, sua atenção será naturalmente atraída pela aparência dos negros. Sua cor, à qual o olho de um europeu não pode se tornar familiarizado por um longo tempo - suas fisionomias selvagens e grosseiras, geralmente tatuados, ou seus membros nus, apenas suficientemente cobertos para atender aos propósitos da decência mínima — sua língua bárbara, e vociferações barulhentas — a selvagem melodia de suas árias nacionais (se o termo pode ser usado), que cantam invariavelmente enquanto trabalham — o ranger das correntes, e as coleiras de ferro usadas por criminosos ou fugitivos nas ruas, - 
estes e outros emblemas peculiares de barbarismo e miséria, tudo concorre para promover a surpresa, $\mathrm{o}$ horror e a repugnância. ${ }^{4}$

Gilbert Mathison compôs esse quadro típico dos olhares europeus para os negros africanos no Rio de Janeiro em 1821. No testemunho desse proprietário de terras inglês encontramos, condensadas, várias das tópicas mais comuns no conjunto dos relatos oitocentistas sobre a cidade: o susto com a multidão negra e seus emblemas - rostos feios, marcas corporais, seminudez, uma língua estranha e incômoda, canções incompreensíveis e, por fim, o acinte dos castigos físicos. Aproximadamente duas décadas após a visita de Mathison, já haviam sido publicadas no mercado editorial europeu muitas das obras que, ainda para seus contemporâneos, passaram a compor as referências de viagem mais conhecidas e citadas sobre o Brasil, incluindo os livros de Jean-Baptiste Debret, Johann Moritz Rugendas, Spix e Martius e Auguste de Saint-Hilaire.

Entre esses nomes inclui-se a produção do historiador francês Jean Ferdinand Denis, que visitou o país várias vezes, exatamente no mesmo período da permanência de Debret na Corte imperial (1816-1831). O convívio prolongado do historiador no Rio de Janeiro permitiu-lhe colecionar inúmeras descrições e valorações a respeito dos negros e suas heranças africanas. Neste caso, o livro de Denis - por seu formato que mescla relato de viagem (no sentido estrito da expressão) a um gênero mais ensaístico - é um bom condutor para as discussões que queremos pontuar. No item "Diversas raças a que os habitantes pertencem”, o autor introduz o leitor numa descrição gradativa do universo dos negros na cidade:

O que em primeiro lugar excita a admiração de quem se aparta dos bairros mais particularmente habitados por europeus é o excedente desta população negra ... Os negros estabelecem entre si diferenças específicas: há os negros que vêm diretamente da África, negros moleques; há os negros nascidos no Brasil, crioulos, únicos que recebem uma denominação reservada em nossas colônias aos brancos nascidos no país ...

Uma das coisas que chocam sempre o estrangeiro quando chega à rua que conduz à alfândega, é essa reunião de negros, pertencentes a tantas raças africanas, e que um primeiro golpe de vista confunde sempre: a sua seminudez, porque apenas usam uns calções de pano de algodão; esses robustos membros que evocam as mais belas formas da estatuária antiga, essas tatuagens bizarras, que servem de pronto para conhecer as diversas nações, este tumulto que quase sem- 
pre acompanha a menor operação confiada aos negros, esta espécie de harmonia compassada da voz, que a ela se segue e que deve sempre marcar a marcha quando conduzem algum fardo, tudo isto forma um quadro, a que em breve se torna indiferente, sem dúvida, mas que espanta à primeira vista, como a revelação de um mundo desconhecido, do qual mil nuanças há que estudar. ${ }^{5}$

Denis constata, a princípio, o susto causado pelo número de negros, mas logo vai além, indicando as divisões entre os africanos e crioulos. Em seguida, alerta para o equívoco de se considerar todos os africanos iguais, como um primeiro olhar poderia supor ao vê-los seminus: ao contrário, os sinais imediatos de distinção entre eles estariam justamente em seus corpos, nas escarificações, que distinguiriam entre si as "diversas nações", ou as "tantas raças africanas”. Para ele, como para vários outros autores do período, os termos 'raça' e 'nação' são sinônimos. ${ }^{6}$ Finalmente, o francês destaca ainda mais um elemento evidente de africanismo: a marcação vocal que pontuava os trabalhos dos carregadores. Assim, este quadro de impacto inicial em relação aos africanos se faz através do estranhamento visual e sonoro, e do incentivo ao estudo atento das "mil nuanças" daquele mundo desconhecido, que deveria sobreviver à natural indiferença subseqüente.

Outros viajantes contemporâneos chamaram a atenção para a peculiaridade do Rio de Janeiro como ambiente propício à observação dos africanos. Referindo-se ao grande número de imagens de negros em sua obra, Rugendas afirma:

se alguém julgar que em semelhante viagem dois cadernos de figuras de pretos são demais, queira considerar que o único lugar da Terra em que é possível fazer semelhante escolha de fisionomias características, entre as diferentes tribos de negros, é talvez o Brasil, principalmente o Rio de Janeiro; é em todo caso, o lugar mais favorável a essas observações. Com efeito, o destino singular dessas raças de homens traz aqui, num mesmo mercado, membros de quase todas as tribos da África. Num só golpe de vista pode o artista conseguir resultados que, na África, só atingiria através de longas e perigosas viagens a todas as regiões dessa parte do mundo.

A tônica de que o Rio era uma vitrine bastante adequada para se notar a diversidade africana em suas 'raças', 'tribos' ou 'nações' foi expressa em várias ocasiões e sentidos nesse conjunto de literatura de viagens. Quatro anos de- 
pois do lançamento do livro do pintor bávaro, o professor de geografia e história francês Ramière d'Elvas menciona-o para respaldar seu argumento:

O Sr. Rugendas fez observar com muita razão que o Brasil é, de todas as partes do mundo, aquela onde se podem fazer mais facilmente observações sobre as diferentes raças de negros. No Rio de Janeiro sobretudo, o observador pode obter de um só golpe de vista resultados que em África mesmo ele não alcançaria a não ser fazendo longas e perigosas viagens em todos os países dessa parte do mundo. Esta observação plena de verdade merece toda a atenção do fisiologista, e tentaríamos desenvolvê-la se os limites desta pequena obra nos permitissem... ${ }^{8}$

Para Rugendas, os negros do Rio correspondiam a um terreno fértil para os artistas; Elvas já opinava que seriam os fisiologistas os que mais poderiam tirar proveito daquele universo humano. O tenente Carl Skogman, anos mais tarde, apontou ainda outra área que o tema atrairia: "para aquele que se interessa pelos estudos etnográficos, os numerosos escravos ofereceriam sem dúvida um vasto campo de observações, ainda que fosse necessária uma permanência prolongada para poder chegar a resultados de algum valor.". Embora tenha utilizado a categoria 'escravos' para designar os negros, a seqüência do texto indica claramente que o militar sueco referia-se aos africanos, ao mencionar as nações de procedência e as tatuagens que marcavam seus corpos (Skogman, 1942, p.23). Essa justaposição de significados entre os termos 'escravo', 'negro' e 'africano' é facilmente flagrada nos escritos dos viajantes da época, sobretudo entre as décadas de 1810 e 1840 . O príncipe Maximilian de Vied Newvied, ao traçar um quadro racial do Brasil, evidencia essa idéia. Nomeia como 'negros' (e transcreve a palavra em língua portuguesa) os "negros africanos puros, também chamados mullecos". ${ }^{10}$ Ferdinand Denis também sugere esse jogo de sentidos. Insistindo em seu propósito investigativo das distinções entre os africanos, prossegue seu relato escolhendo a rua da Alfândega como um cenário no qual se desenrolavam espetáculos e relações notáveis:

Nada mais animado, mais variado que a Rua da Alfândega: aqui, são pretas levando a cesta cheia de frutos, que acabam de colher nas quintas de seus senhores e vão colocar no mercado; outras, como antigas canéforas, balançam uma urna sobre suas cabeças; mais longe vê-se uma negra crioula ricamente ornada com sua camisa guarnecida de renda, e com longos cordões de ouro. Esta vai cumprir algum mandado; e se a nudez de seus pés atesta a escravidão, a indo- 
lência de seu caminhar prova quanto ela se julga superior às suas companheiras, que a olham com inveja.

Mas, nesta hierarquia da escravidão, se se fica surpreso com o que a riqueza dos trajes estabelece, ou somente a opulência do senhor, uma coisa choca ainda mais: são as velhas lembranças da África que sobrevivem ao cativeiro. Este negro, que se vê à parte, é muitas vezes um chefe, ao qual se respeita, e que reencontra sempre o seu poder quando alguns vão consultá-lo. Este músico solitário, que escuta com tanta atenção os sons melancólicos do seu banzo ou de seu balafo, é algum bardo semi-selvagem, que não ignora o seu poder, e basta-lhe uma ária mais rápida ou um canto mais apaixonado, para ver acudir a seu redor os que domina por seu entusiasmo, e que reconhecem como inspirado. Aqui se vê o negro de Moçambique que despreza o negro do Congo; acolá, o habitante da Mina zomba do Coromantim. Assim, nesta população, tão uniforme em aparência, no meio destes homens que a escravidão parece ter nivelado, há transmissão do poder guerreiro, é reconhecida a supremacia da inteligência, presencia-se a luta das nações; é, não duvidemos, o que imprime uma feição tão singular a esta população escrava, cujos costumes são muito pouco estudados. (Denis, cit., p.126)

Nessa cena, as escravas são designadas por 'pretas', provavelmente como sinônimo de africanas, pois o autor estabelece uma oposição entre elas e a negra que especifica como 'crioula' e, neste caso, a "hierarquia da escravidão" a que se refere não se traduz somente na riqueza dos trajes, mas também na rivalidade de origem, pela qual os escravos crioulos se julgariam superiores aos africanos. Denis prossegue seu reconhecimento dos africanismos espantando-se com o poder de liderança de um músico africano e registrando disputas entre as nações. Assim, o autor traduz como formas de organização social civilizadas ("transmissão do poder guerreiro", consideração da "supremacia da inteligência", e existência da "luta das nações") as manifestações de negros que, supostamente, a escravidão poderia ter 'nivelado' - aqui, no sentido de desagregar ou destituir de particularidades. Em outras palavras, o historiador francês defendia a idéia de que a escravidão não foi, de maneira alguma, um elemento desintegrador das identidades africanas. Ao contrário, acreditava que o exercício dessas identidades era justamente a mola mestra de suas condutas sociais, ou a principal característica daquela população escrava. Por isso, insistia sempre no caráter capcioso de um olhar externo que enxergasse uniformidade entre os negros: 
Nós o repetimos: essa população negra, composta no Rio de Janeiro de tantas tribos diferentes, é exatamente o que imprime na massa em geral seu traço de originalidade. Essas librés tão extraordinárias e algumas vezes tão ricas, que trazem os pretos domésticos, esses toucados singulares, que distinguem as tribos entre si, assim como as várias tatuagens, esses costumes locais, que a escravidão não faz senão modificar e que lembram sempre a África no meio da civilização européia, todos esses contrastes de costumes, de trajes, de graus de civilização, dão à população negra daquelas regiões um caráter que persistirá largo tempo ainda, e que só se extinguirá quando as últimas disposições, que anulem comércio de escravatura, tiverem recebido toda sua execução. (Denis, cit., p.156-7)

A avaliação de Denis sobre a escravidão no Rio de Janeiro da primeira metade do século XIX tem, portanto, a diversidade africana como elemento central, reafirmada tanto por meio de sinais corporais (penteados e tatuagens), vestimentas e hábitos, até a reprodução (ou recriação) de instituições e códigos sociais. Embora, às vezes, seu texto se refira à África como 'lembrança', o tom de seus argumentos nos permite conclusões mais profundas a respeito dos significados que imprimiu às expressões que observou e descreveu. Não eram simples reminiscências, mas efetivamente formas de organização no cativeiro. A esse respeito, há ainda outra idéia veiculada pelos viajantes e, como se sabe, comungada por várias instâncias dos poderes senhoriais: a associação das identidades africanas à maior ou menor capacidade de insurgências entre os negros (escravos e livres). Fazendo uma breve escala na cidade do Rio de Janeiro em 1816, um comissário da embaixada inglesa na China notou:

O perigo de insurreição, que deve ser apreendido da grande proporção existente entre os escravos e o resto da população, é em alguma medida neutralizado por pertencerem a nações da África diferentes entre si na língua e nos costumes, não possuindo nenhum ponto de similitude ou união, salvo sua condição como escravos. Na Bahia, a capital anterior do Brasil, onde os escravos são geralmente de uma nação, insurreições são freqüentes. ${ }^{11}$

O autor leva ao limite o efeito desagregador das diferenças culturais existentes entre os povos africanos, não cogitando nenhuma hipótese de que pudessem ser minimizadas ou modificadas pelas vivências da escravidão. Para confirmar seu argumento, cita o caso da Bahia, onde uma procedência africana uniforme teria propiciado maiores chances de rebeliões. Na década de 
1830, em formato mais carregado e prolixo, as palavras do oficial francês Cyrille Laplace reforçaram essa visão:

Pernambuco e Bahia já teriam, provavelmente, se livrado do jugo de um governo tão desprovido de meios de se fazer obedecer, e cujas finanças estão no grau máximo de desordem, se não temessem tanto uma perturbação da ordem. [Essas províncias] correm, com efeito, um perigo bem mais iminente do que a capital, onde os brancos e mulatos não têm a conter mais do que uma pequena quantidade de negros - malvados, é verdade, inclinados ao homicídio e à pilhagem, mas tirados de diferentes países da África e, por conseguinte, incapazes de algum acordo... ${ }^{12}$

E, continuando a se referir aos povos africanos unidos pela origem:

Eles formam uma raça negra numerosa, homogênea, determinada, inteligente e temível sobretudo pela perfeita união de seus membros que, livres ou escravos, obedecem cegamente aos mais opulentos de sua casta. Esta união, cimentada pelas relações naturais que estabelecem entre os negros uma mesma origem, uma mesma linguagem e religião, é tanto mais perigosa para os outros habitantes porque estes negros se aliam somente entre si e suas mulheres não se entregam aos europeus senão a muito custo ... Concebe-se facilmente, a partir disso, que o menor abalo político pode fazer tombar o poder nas mãos desta população negra que, fortemente disposta a tomá-lo, produziria sem dúvida, na Bahia e em Pernambuco, a mais pavorosa anarquia. (Laplace, cit., p.131)

O vaticínio de Laplace se concretizou no mesmo ano da publicação de seu livro de viagem, com a revolta na freguesia de Carrancas em Minas Gerais e, em 1835, com o levante dos Malês em Salvador. Mas, apesar de fazer coro com Ellis ao estimar os perigos políticos advindos da união entre negros que compartilhavam uma determinada cultura, esse autor contraria todos os dados demográficos e relatos de viajantes que testemunham a grande afluência de africanos da cidade do Rio de Janeiro durante a primeira metade do século XIX. Em seguida, uniformiza o caráter dos africanos ao apontá-los com tendências para crimes, mas logo ressalta o fator de desunião que os impediria de agir. Os negros da Bahia e de Pernambuco, ao contrário, teriam condições bem favoráveis para se entenderem e se rebelarem: uma procedência geográfica africana comum, a língua e a religião.

Comparar o conjunto dos registros das particularidades dos escravos 
africanos e de suas diferenças internas produzidos por viajantes é tarefa nada fácil, pois, muitas vezes, as impressões mesclam uma gama de crivos que, ao mesmo tempo recorrentes entre os autores, sofrem deslocamentos de sentidos e assumem diferentes hierarquias no interior de cada texto. Alguns padrões, entretanto, são mais seguramente observáveis, e vimos até aqui amostras disso: descrições e valorações acerca das formas dos corpos, suas marcas, vestimentas e adereços; a linguagem, danças e canções incompreensíveis e, por fim, traços de índole ou caráter.

A maioria desses discursos é informada por um repertório conceitual germinado e cristalizado ao longo das últimas décadas do século XVIII. Em poucas palavras, aquelas produções, formuladas em searas das ciências naturais e das teorias estéticas, compreendiam a África como um continente determinante de uma gama de características humanas físicas e comportamentais. Alguns desses atributos eram tidos como inerentes a qualquer negro, mesmo não nascido na África, mas que carregava em seu corpo e mente as heranças indeléveis de sua ascendência. ${ }^{13}$ Justamente por isso, a freqüente fluidez encontrada, nos livros de viagem, entre os termos 'negro' e 'africano'. A seguir, examinaremos algumas formas pelas quais os viajantes se apropriaram de tal repertório.

\section{CORPOS, SINAIS E EXPRESSÕES}

Ferdinand Denis, ao descrever os membros corporais dos escravos africanos, comparou-os às "mais belas formas da estatuária antiga" (Denis, cit., p.125), e as negras vendedoras de frutas seriam para ele "como antigas canéforas" (p.126). A recorrência dos viajantes oitocentistas a modelos estéticos greco-latinos para qualificar os corpos africanos é respaldada por um interesse surgido mais fortemente ainda no século XVIII, nas academias de belas-artes européias, pela representação plástica dos negros. A esse respeito, é sintomático um artigo de Joshua Reynolds, publicado num jornal londrino em 1759:

É o costume somente que determina nossa preferência pela cor dos europeus em detrimento da dos etíopes; e eles, pela mesma razão, preferem sua própria cor à nossa ...

Suponho que ninguém duvidará se um de seus pintores fosse pintar a deusa da beleza e a representasse negra, com lábios grossos, nariz achatado e cabelos 
de lã; e parece-me que ele agiria de forma nada natural se assim não o fizesse ... Nós, de fato, dizemos que a forma e a cor do europeu são preferíveis às do etíope, mas não conheço razão para isso a não ser o fato de que estamos acostumados a elas. É um absurdo dizer que a beleza tem poderes atrativos que irresistivelmente tomam a mente de amor e admiração, pois este argumento é igualmente conclusivo em favor do filósofo branco como do negro.

As nações negras e brancas devem, com relação à beleza, ser consideradas como diferentes tipos; ao menos uma espécie diferente do mesmo tipo, de cada uma das quais, como observei, nenhuma inferência pode ser esboçada. ${ }^{14}$

Com essas palavras, Reynolds dava uma resposta crítica às teorias de Edmund Burke sobre as noções de belo e sublime, segundo as quais a negrura induziria ao terror a mente de seu observador, por motivos de ordem fisiológica. O relativismo estético do pintor inglês destoava da maioria das opiniões eruditas coevas e posteriores, é verdade. De qualquer modo, o empenho em exercitar o olhar para os modelos negros já estava consolidado no início do século XIX. Segundo Hugh Honour (cit., p.23), "estes homens bem talhados representavam para os artistas 'belos espécimes' viris nos quais o vigor e a flexibilidade compensavam vantajosamente sua pretensa falta de inteligência ou afetividade". Esse autor evidencia a oposição conceitual européia criada entre o belo corpo dos negros e seus defeitos não físicos. Os viajantes também apontam esse contraste e mais outros: entre os corpos e os rostos, ou entre corpos e cor da pele. ${ }^{15}$ Comecemos pelas impressões dos aventureiros prussianos Johanes von Leithold e Friedrich Rango, de 1819, dos quais se sabe apenas que vieram ao Brasil na tentativa de se estabelecerem como fazendeiros, mas logo retornaram à Europa:

Os escravos negros, que no Rio de Janeiro chamam de moleques, vêm de Angola ... São muito pretos de cor — ambos os sexos — e de traços tão feios que parecem caricaturas. Em compensação, suas proporções físicas são bem regulares, tanto no sexo masculino quanto no feminino. ${ }^{16}$

Mais de duas décadas depois, o príncipe Adalbert Ferdinand, também vindo da Prússia, fez a mesma ponderação: “As figuras dos negros são freqüentemente bonitas, e em geral fortemente constituídas; seus rostos, ao contrário, são quase sempre horrendos, especialmente os das mulheres". ${ }^{17} \mathrm{Em}$ 1820, o diplomata inglês James Henderson já mostrava esse tipo de comentário, ainda mais enfático, mas sem mencionar os traços faciais: 
Muitos dos negros escravos são notadamente bem formados, particularmente alguns dos que trabalham na alfândega, e exibem muita força muscular em toda sua estrutura, combinada com tal simetria de formas que o alinhamento e os músculos intumescidos de seus corpos nus lembraram-me alguns belos modelos antigos. ${ }^{18}$

De fato, os carregadores de fardos mais pesados constituem a tópica mais citada quando os viajantes fazem referências à força muscular e ao corpo bem moldado dos africanos, quase sempre os comparando a personagens e metáforas greco-latinas ou neoclássicas. Jean-Baptiste Debret também registrou essa associação, mas tomando como exemplo a figura de um fabricante e vendedor de cestos, cuja litografia ganhou a seguinte descrição:

Sua vestimenta constitui-se, em geral, de um amplo calção, apertado na cintura por uma cinta de sarja de lã, e de uma camisa, enrolada em volta do corpo e amarrada por detrás de modo a deixar pendentes as mangas. O gorro, que substitui o boné de lã, é realmente escocês: restos de uniformes militares de um destacamento de tropas escocesas contratado para o serviço do Imperador e licenciado pouco depois.

A guirlanda de folhas leves, que se poderia tomar por um enfeite selvagem inútil, tem no entanto a dupla vantagem de resguardar do sol parte do peito e de provocar certo frescor ao sopro do vento. Pelo bracelete observa-se a mania desses homens robustos, que se comprazem em comprimir os músculos perto das articulações.

O bastão, verdadeiro augural egípcio, revela pela cabeça do animal toscamente esculpida, em que se aproveitou um galho engenhosamente talhado e descascado a fim de imitar a brancura de um corpo estrangeiro, esse caráter de um modo marcante.

$\mathrm{O}$ artista e o antiquário reconhecerão no conjunto deste ingênuo carregador de cestos o tipo imperecível das esculturas gregas e egípcias. ${ }^{19}$

Esse trecho revela uma amostra da opacidade do olhar eurocêntrico de Debret. Nada em sua descrição reconhece qualquer signo africano na figura do negro, salvo referências à cultura material egípcia. Mas neste caso, é possível que o pintor estivesse se valendo de uma tese do alemão setecentista Johann Winckelmann, segundo a qual a arte egípcia era caracterizada por bizarrices, destituída da preocupação em construir expressões do belo. Para esse historiador da arte, o progresso egípcio foi impedido por uma mentalidade 
rigidamente atada a suas leis e costumes religiosos e civis. Tal sociedade, assim configurada, teria prejudicado os artistas, desvalorizando-os e abandonando-os à pobreza, fracassados em suas tentativas de expressar as idéias de belo e sublime. Neste sentido, estaria situada, pelas teorias winckelmannianas, no estágio civilizacional da necessidade, que antecedia o da beleza. Além disso, os egípcios teriam sido menos favorecidos pela natureza do que os gregos e etruscos, não constituindo, pois, um povo tão bonito quanto os dois últimos. Por fim, sua mórbida fixação pela vida após a morte teria sufocado qualquer aptidão para alegrias e prazeres, tornando-os sombrios e melancólicos (ver Bindman, cit., p.85-6).

Winckelmann foi um dos principais teóricos da estética neoclássica. Seus principais escritos, lançados entre as décadas de 1750 e 1760, defendem a existência de um 'belo' ideal e universal, que não estaria na natureza, mas no espírito do homem. Para ele, os artistas que mais se aproximaram de suas formas foram os gregos do período clássico e, mais tarde, os renascentistas italianos, porque se haviam inspirado justamente nos gregos antigos. É fundamental lembrar que os pilares conceituais desse historiador caracterizam uma teoria climática segundo a qual as condições ambientais ideais da Grécia clássica propiciaram o desenvolvimento da perfeição física entre aquele povo, bem como um cenário político e social altamente favorável. Essa confluência tão feliz de elementos teria se materializado nas esculturas: peças da mais alta qualidade estética que, partindo de modelos vivos que já possuíam formas privilegiadas, conseguiram atingir as formas ideais das proporções e beleza humanas. Os egípcios e os gregos corresponderiam então, respectivamente, aos pólos positivo e negativo daquilo que Winckelmann considerava como produção artística no mundo antigo. ${ }^{20}$ Quando Debret sugere uma analogia entre o vendedor de cestos e as esculturas gregas e egípcias parece reunir essa dicotomia numa mesma figura. O corpo do negro, robusto e musculoso, estaria inscrito na tradição clássica; mas seu bastão, talhado toscamente, evocando algum animal auspicioso, lembraria a arte egípcia antiga.

Já Ernst Ebel, contemporâneo tanto de Henderson quanto de Debret no Rio de Janeiro, dedicou-se a discernir as belezas africanas pelo critério do gênero:

Na maioria, os homens são bem proporcionados e muitos vi que poderiam servir, sem dúvida, de modelo para um Antínoo; há mesmo os cujos corpos, marrom-escuro, posta de lado minha natural preferência pela cor branca, merecem ser considerados verdadeiramente belos. ${ }^{21}$ 
Percebe-se que esse viajante letão discordava das qualidades da pele negra defendidas por Joshua Reynolds. Com relação às mulheres, foi menos generoso ainda:

As mulheres são no geral feias e mesmo de corpo deixam a desejar, tendo forte tendência para a gordura, mas seus braços são comumente bonitos, os pés e as mãos pequenos, finos até, apesar de não se calçarem. Muitas são tatuadas ou marcadas no rosto com luas, estrelas e mais sinais característicos. A outras faltam os dentes incisivos de cima ou limam-nos em ponta, processos esses de embelezamento africano que as tornam francamente horrendas aos olhos de um europeu. (Ebel, 1972, p.46)

Para Ebel, portanto, havia várias ressalvas em relação aos padrões de beleza observáveis entre os africanos. Em primeiro lugar, a pele negra era peremptoriamente um valor negativo, e as mulheres raramente ofereciam às vistas dos estrangeiros as formas clássicas encontradas nos homens, portando, além disso, marcas faciais que aumentavam sua feiúra. Confirmando suas conclusões por meio da exceção, ele ainda registrou:

Em casa de Herr Theremin vi pela primeira vez uma negra bonita, que, abstração feita da cor, poderia servir de modelo para uma Vênus, tão perfeita era de formas, como no porte e mesmo nos traços fisionômicos. Todavia, no caráter não difere vantajosamente de suas conterrâneas, por mais bem tratada que seja pelo seu senhor. (Ibidem, p.125-6)

Mas esse viajante não foi o único a evocar a imagem da deusa romana da beleza. Georg Freireyss, discordando da avaliação de um terceiro a esse respeito, pondera:

Os negros se distinguem de ordinário por grande beleza de formas, o que às vezes também acontece com as negras. O Sr. Langsdorff, porém, segundo a minha opinião, excede-se quando acredita ser mais fácil encontrar entre as negras a Vênus de Médici e teria certamente de perder muito tempo, mesmo se ele a procurasse sem a cabeça da Vênus e da cor inimitável da mulher européia. ${ }^{22}$

O naturalista alemão refreia, pois, o entusiasmo de Langsdorff com relação aos belos corpos femininos, mesmo reconhecendo suas qualidades. Além disso, reitera o valor negativo da pele negra e dos traços fisionômicos africanos e continua, no mesmo propósito depreciativo: 
As negras têm geralmente peitos flácidos e pendentes e somente as moças muito novas os têm de uma forma que satisfaz nossas idéias de beleza, e não é ao clima que se pode atribuir isso, mas sim ao vestuário solto que raras vezes se compõe de mais de uma camisa e uma saia. Nunca vi um só caso, como contam os viajantes, de que as mães amamentassem os filhos que traziam nas costas com o peito jogado por cima do ombro: porém muitas vezes vi que, mesmo durante o trabalho, a criança se enfiava por baixo do braço da mãe para mamar. (Freireyss, 1982, p.126)

Embora esse autor afirme não ter presenciado aquela peculiar maneira de amamentar, todos os registros a esse respeito associam a prática, e outras semelhantes, a um costume marcadamente africano. Antagonizando o testemunho de Freireyss, o soldado alemão Eduard Bosche avalia:

Entre as negras filhas de Eva encontram-se no seu gênero verdadeiras belezas.

Destacam-se muitas pela estatura elegante, harmonia e plenitude das formas. Têm a maior parte uma graça natural e uma majestade inata. Seu andar e seu porte permanecem soberbos e imponentes, mesmo quando carregam fardos pesados, os quais levam sobre a cabeça.

Quando se tornam mães desaparecem logo tais atrativos. Os seios intumescidos, fortes e rijos tornam-se moles, murchos, caindo até o umbigo. Acontece freqüentemente que amamentam atirando as tetas por cima do ombro, pois levam as crianças às costas, ou presas ao quadril. ${ }^{23}$

Robert Walsh, por sua vez, traz outros elementos para nossas ponderações plásticas. Visitando o Rio de Janeiro entre 1828 e 1829, confessa seu espanto:

A diferença de casta é muito fortemente marcada pela cor de suas peles, e ainda mais na expressão de suas fisionomias, num grau do qual eu não fazia idéia. Antes de vir ao Brasil, eu não podia distinguir um negro do outro mais do que um carneiro num rebanho; mas neste país acudiu-me que a variedade da face humana era ainda mais fortemente marcada na cor negra do que na branca: a gradação da última ia somente do bonito ao feio; mas na primeira, ia do bonito ao medonho; e acho que encontrei entre estes rostos escuros alguns dos mais atraentes e dos mais revoltantes aspectos naturais ...

A superioridade da população de cor é não só maior em número mas em força física. Alguns negros e mulatos são as pessoas mais vigorosas e atléticas que 
se pode contemplar, e que poderiam ser modelos para um Hércules de Farnese. Sua estrutura muscular natural é enrijecida e aprimorada pelo exercício; e quando as fibras são dilatadas por alguma ação laboriosa, exibem uma magnífica figura de força e atividade. ${ }^{24}$

Descobrindo a existência de nítidas diferenças físicas entre os negros por meio dos critérios de cor da pele e fisionomias, o pastor irlandês constrói dois leques de gradações de belezas faciais: entre os brancos, os rostos variavam apenas de 'bonitos' a 'feios'; já entre os negros, esse espectro aumentava num dos pólos, apresentando exemplos que poderiam chegar ao 'medonho'. Apesar disso, ele também não consegue fugir do padrão que associava aqueles corpos a um ideal estético clássico.

Assim, já podemos vislumbrar mais concretamente quais os juízos mais comuns, entre os viajantes, a respeito da beleza dos africanos. Em consonância com um contexto intelectual e artístico europeu solidificado em fins do século XVIII, a cor escura era considerada desprovida de beleza, assim como traços e sinais faciais que fugissem dos padrões então delineados. Porém, foi-se reiterando que o lugar da beleza negra residia essencialmente nas formas corporais, por se encaixarem em modelos valorizados que evocavam conceitos apolíneos de proporções e desenvolvimento dos membros. No conjunto dessa literatura de viagem, é raro encontrarmos uma descrição como a de Carl Schlichthorst, tenente de granadeiros alemães do Exército Imperial de Pedro I:

Os pretos são todos geralmente de estatura mediana e as mulheres um pouco menores que os homens ... Os braços e as pernas são bem fornidos de carne, como os das classes trabalhadoras da Europa. A nuca é excessivamente forte, talvez devido a carregarem todos os pesos à cabeça. A coluna vertebral se afunda na carnadura. Os ombros e as costelas arqueiam-se salientes. Isto e peitos de construção mais feminina são características da raça, havendo alguns inteiramente imberbes ...

Em verdade, os negros, como os carneiros, não têm fisionomias próprias, a diferença de feições é tão pequena entre eles que isso só não basta para distingui-los uns dos outros. Parece que é fácil confundi-los. Entretanto, suas raças apresentam traços característicos fisionômicos os mais diversos. ${ }^{25}$

Aqui, temos o exemplo de um uso elástico do conceito de raça, que serve tanto para designar os pretos em geral como subdivisões entre eles, geradas por traços fisionômicos. O militar de nome impronunciável, excepcionalmen- 
te, não faz nenhuma menção a formas greco-latinas. Embora seu registro seja construído por critérios essencialmente anatômicos, a comparação se dá com os trabalhadores europeus, sem maiores especificações. E, assim como Walsh, o viajante exemplifica a aparente uniformidade dos rostos negros lembrando o caso dos carneiros.

Um outro tenente, o sueco Skogman, que visitou o Rio de Janeiro em 1851, acrescentou dados de outra natureza ao observar a diversidade africana:

As distintas classes de negros se diferenciam em parte por seu físico e em parte pelos adornos, característicos para cada grupo. Alguns, por exemplo, estão tatuados; outros têm seus rostos sulcados por cicatrizes que em alguns casos correm de uma bochecha à outra, e em outros as sulcam de cima para baixo. Outros, enfim, ostentam uma fila de verrugas provocadas artificialmente que vão deste o nascimento do cabelo até a extremidade do nariz. Inútil destacar que estas cicatrizes e demais 'adornos' em nada contribuem para melhorar as fisionomias, já por si tão pouco agraciadas. A maior parte dos negros que se vêem no Rio são de estatura mediana, e somente como exceção se vê um ou outro exemplar fornido e bem desenvolvido. $\mathrm{O}$ mesmo ocorre com as negras, ainda que não por isso deixem de se fazer atraentes a muitos olhos. (Skogman, cit., p.22-3)

Temos a partir desse fragmento, então, outros fatores a considerar além dos corpos em si. Embora termine seu comentário relativizando a feiúra dos homens e mulheres africanos, Skogman impressiona-se com o mau aspecto causado pelo uso de escarificações e tatuagens em rostos que eram, de resto, naturalmente "pouco agraciados". Assim, junto à cor da pele e aos traços fisionômicos, as marcas das culturas africanas também contribuiriam para compor um juízo desabonador acerca de suas belezas. Sobre esses sinais, foi Freireyss quem se preocupou em ensaiar uma explicação mais detida, ainda em 1815. Começa por mencionar as marcas a ferro do tráfico, que serviriam para "rebaixar ainda mais a humanidade" dos escravos para, em seguida, discorrer sobre as tatuagens de forma genérica, afirmando ser este um "costume que se acha introduzido em todos os povos da Terra". Segundo o naturalista, o hábito de marcar os corpos teria surgido entre o "selvagem do estado primitivo" como meio de preservar a memória de feitos excepcionais de bravura, em razão do grande valor dado aos ferimentos de guerra:

Começaram a ter idéias especiais a respeito da forma das cicatrizes, em conformidade com o sentimento de beleza de cada um. Alguns alcançaram a maior 
perfeição em produzir tais cicatrizes pela tatuagem e fizeram disso uma espécie de ofício pago. Quando mais tarde as nações, que antes viviam da caça e da guerra, se tornavam em agricultores, continuou-se uma espécie de ornamentação do corpo, como um sinal de distinção. Essa idéia de distinção prevalecia tanto mais quanto o aumento da civilização e o cuidado pela propriedade, ameaçada pela guerra com os vizinhos, faziam a bravura ser ainda mais apreciada. Neste ponto acham-se ainda milhões de homens e entre eles também os negros de Angola, Cabinda, Benguela etc. As idéias desta gente a respeito da riqueza não estão, porém, inteiramente de acordo com as nossas e acham-se, de ordinário, unidas às idéias de valentia e de bravura. Não é, por isso, talvez sem razão que se afirma serem preferíveis os negros tatuados e afiançaram-me que quanto mais a pele de um negro for tatuada, tanto mais alta tinha sido sua posição, e isto mesmo entre os outros negros tatuados, sendo provavelmente um chefe ou filho de chefe de tribo que tinha sido capturado, com outros, e vendido aos portugueses. (Freireyss, cit., p.124-6)

Pelo raciocínio de Freireyss, as tatuagens e escarificações não somente seriam úteis para distinguir os membros advindos de cada nação africana, mas também para denotar hierarquias sociais internas e, neste caso, perante os olhares senhoriais, a existência e a quantidade dessas marcas em corpos africanos poderiam indicar um bom negócio, a aquisição de homens valorosos.

Uma passagem de Jean-Baptiste Debret, após afirmar que "os escravos importam tatuagens variadas, que distinguem as diferentes nações", descreve seus usos pelas negras ambulantes:

A tatuagem é praticada de diversas maneiras, por incisões de inúmeras formas, gravuras pontilhadas ou simplesmente linhas coloridas. No Rio de Janeiro é esta a maneira mais comum e pode ser observada diariamente nas negras, a isso levadas pela saudade da pátria. Assim, de manhã, por exemplo, quando essas vendedoras se reúnem na praça de legumes, basta que uma das mais alegres entoe uma canção africana, balançando-se com gestos específicos, para que todas, subitamente eletrizadas e frenéticas, no auge do entusiasmo e procurando sobrepujarem-se umas às outras, lancem mão de tudo o que encontram para se tatuar, desde o simples barro até a cal. Mas a máscara grotesca que conservam o mais das vezes acaba eletrizando também os machos, do que elas se aproveitam para conseguir o oferecimento de um ou mais cálices de cachaça ou algumas guloseimas; e é raro que tanto galanteio não termine em encontro noturno, mo- 
mento delicioso que, quando demasiado prolongado, acarreta uma bela punição para a bela tatuada. (Debret, cit., p.146)

Ao descrever as pinturas faciais ou marcas temporárias à guisa de tatuagens usadas por um grupo específico de negras, o pintor associa a prática às saudades da África, mas também indica certas rivalidades estéticas em torno ao procedimento, também associado diretamente aos cantos e danças e, neste caso, desdobrando-se ainda em estratégias de sedução acionadas pelas africanas.

Passando pela rua Direita no mesmo ano da partida de Debret, William Ruschenberger, oficial da marinha norte-americana, nota uma animada dança de negros ao som da marimba, dando destaque para um detalhe do músico:

Quando nos aproximamos, a dança cessou, e os negros abriram caminho para passarmos. Chamei o músico, do qual examinei o instrumento. Ele sorriu e pareceu grato pela atenção. Era jovem e cheio de saúde, mas com a mais estúpida expressão facial, produzida por uma corrente de nódulos carnudos, estendendo-se da ponta de seu nariz numa linha sobre sua testa; quando sua atenção não estava ocupada de outra forma, seus olhos estavam sempre direcionados para esta marca distintiva ... Eu perguntei sobre a origem das protuberâncias, e Brunner me informou que é uma espécie de tatuagem, feita na infância por seus pais, designada como uma marca de distinção da tribo. Ele apontou, na nuvem [de negros] ao nosso redor, um cuja face era arranhada ou talhada numa das bochechas; outro marcado do mesmo modo em ambas; alguns em suas têmporas; alguns em seus peitos e costas; e havia um que tinha cada um dos dentes cortados em diagonal.... ${ }^{26}$

Em seguida, desdobrando o mote das diferenciações faciais, o oficial infere:

A miséria comum não fez os negros esquecerem as rixas de suas tribos, pois eles trouxeram mútuos e talvez hereditários ódios consigo, e se supõe que a segurança dos brancos, que são em bem pequeno número, depende sobretudo desta circunstância. Embora isso possa ser parcialmente verdade, suspeito que a apatia, que é uma característica das raças africanas, é a razão pela qual eles não se levantam en masse e destroem seus senhores. (Ruschenberger, 1834, p.30)

Para Ruschenberger, portanto, as escarificações tinham um significado mais profundo além de idiossincrasias estéticas: eram um indício visível, ostentado pelos africanos, de suas rivalidades acirradas - fator que, primordialmente, impediria rebeliões. Entretanto, logo em seguida, nivela todos os 
negros ao palpitar sobre a natural apatia que seria inerente a todas as 'raças' da África. O movimento feito por esse viajante, de introduzir o tema das marcas faciais no interior de uma cena de música e dança entre os negros foi repetida por Maximilien Radiguet, que esteve no Rio em 1844:

Encontramos um dia, perto da fonte, escravos que dançavam a bamboula ao som de uma espécie de bandolim. O músico era um velho; seus cabelos lhe cobriam a testa como uma lã branca, e uma tatuagem bizarra traçava-lhe, do topo da testa até a ponta do nariz, uma linha de inchaços semelhante a um rosário de verrugas.

O estardalhaço de risos insanos, as contorções e os movimentos exorbitantes dos dançarinos mostravam quão pouco eles se incomodavam com o calor; pode ser mesmo que esta companhia, a única que lhe foi fiel na terra estrangeira, contribuísse para apagar as lembranças de sua escravidão, para reavivar aquelas de sua infância livre e alegre... ${ }^{27}$

Assim como no capítulo anterior, podemos detectar outras tópicas narrativas acionadas pelos viajantes para compor quadros de estranhamento com a diversidade africana no Rio de Janeiro. Nos casos exemplares de Ruschenberger e Radiguet, o horror perante as escarificações aparece ambientado em passagens maiores, que apresentam outros africanismos flagrantes, como a música e a dança promovidas por grupos de negros. William Ouseley, que passou pelo Rio de Janeiro em 1810, foi um dos primeiros viajantes do século XIX a ensaiar essas aglutinações de signos:

Em certos feriados, [os escravos] obtêm permissão para se juntarem em bandos de quinze, vinte ou mais, de acordo com seus distritos e dialetos nativos; os chefes estando, às vezes, espalhafatosamente enfeitados com contas e plumas, botões velhos, pedaços de vidro e marcas de distinção similares. Entre os membros de cada grupo havia geralmente dois ou três músicos, que executavam suas árias nacionais em diferentes instrumentos, alguns rudes e simples; outros, de formato estranho e complexo. Aqueles sons, entretanto, pareciam deleitar os escravos que cantavam e dançavam com um ar de sincera alegria, tão fortemente, tão naturalmente demonstrada, que não pude nem por um momento supor que era fingimento. ${ }^{28}$

Antes de tratarmos, porém, das expressões de canto e dança africanas registradas pelos viajantes, continuemos no âmbito dos corpos. Aqui, temos a 
menção a acessórios utilizados pelos africanos de hierarquia superior, em algumas ocasiões festivas. Comparativamente a outros temas que remetem diretamente à origem africana dos negros no Rio de Janeiro, as referências a roupas e adornos não são muito comuns na literatura de viagem estudada. A maioria dos relatos reitera a presença da diferenciada multidão africana através de outros sinais: os cantos dos carregadores, as formas físicas bem dotadas, os feios e grosseiros traços fisionômicos, as impressionantes tatuagens e escarificações e, por fim, a rudeza de seus instrumentos musicais e o grotesco de suas danças.

Se nos voltarmos para os documentos iconográficos, poderemos encontrar pistas mais fartas a respeito de vestimentas e ornamentos africanos, sobretudo nas figuras femininas. Há centenas de imagens (gravuras, aquarelas e desenhos) bastante conhecidas, produzidas durante a primeira metade do século XIX que exibem, isoladamente ou em cenários, mulheres negras (escravas ou livres) portando turbantes de diferentes amarrações, colares de contas, o pano da costa num dos ombros, muitas pitando um cachimbo, algumas com os peitos desnudos. ${ }^{29}$ Estes são, efetivamente, os signos mais citados pelos artistas e que nos remetem a um universo estético eminentemente africano. Em contrapartida, nota-se a escassez de legendas ou notas explicativas que explicitem essa condição.

Diferentemente do universo iconográfico, nos fragmentos textuais é possível flagrar com mais precisão, por meio de movimentos e jogos de palavras, quando estão se referindo aos negros como sinônimos de africanos, ou não. Schlichthorst, que considerava os negros destituídos de fisionomias particulares ("como carneiros") mas que, ainda assim, reconhecia a diversidade de traços correspondentes a cada 'raça', assim descreveu as vestes femininas:

É digna de nota a rapidez com que o aspecto dos negros recém-chegados, vantajosamente se modifica com a alimentação abundante e o bom tratamento ... A pele como que se renova e adquire um negror brilhante, os olhos se enchem de vida e fulgor, e em todos os seus gestos as jovens africanas demonstram uma graça natural, que comumente falta à gente da Europa. Trajam-se elegantemente. $\mathrm{O}$ níveo vestido amolda-se aos membros roliços dum brilhante pretume. O turbante vermelho esconde-lhes a carapinha, única coisa que numa preta acho excessivamente feia. Um ombro fica meio descoberto. Do outro cai um pano com cores variegadas... (Schlichthorst, cit., p.132)

A despeito do caráter generalizante dessa descrição, o militar não está se referindo às crioulas e, mais adiante, usa o substantivo 'preta' como termo que 
retoma a alusão anterior, às “jovens africanas”, ressalvando seu aspecto saudável e elegante, seu negror reluzente, a feiúra dos cabelos, a espádua desnuda, o pano da costa - elementos utilizados mais freqüentemente para se caracterizar as mulheres africanas. Retrocedendo alguns anos, encontramos o fragmento de Johann Emanuel Pohl, cientista que veio ao Brasil como membro da expedição austríaca de 1817:

No traje do negro, embora muito simples no conjunto, há, todavia, algumas diferenças. Calças curtas, geralmente muito sujas, e um chapéu, que varia na forma, constituem todo o vestuário de um carregador. Ordinariamente não usa camisa. Outros, ao contrário, trazem camisa e uma véstia azul, aberta. As mulheres andam em geral com saias azuis ou pretas e camisa meio dependurada aos ombros, que deixam a descoberto os desgraciosos seios. As camisas das negras forras são rendadas, deixando ver através a brilhante pele cor de ébano, e elas muito se comprazem com esse ornamento. ${ }^{30}$

Em relação às negras, Pohl destaca dois elementos parecidos aos de Schlichthorst - o tórax seminu e o brilho da cor da pele - , mas em sua descrição nada indica uma aproximação nítida entre os termos 'negro/a' e 'africano/a', ao menos na instância estritamente sintática. Quase quarenta anos depois, contrariamente à descrição genérica do compatriota de Ender, a escritora alsaciana Lina Bernard produziu um registro absolutamente raro sobre o traje das africanas no Rio de Janeiro:

É domingo. Vemos as negras vestidas com o traje oriental da costa da África, com o corpete branco, o turbante de musselina, a peça de tecido feita echarpe lançada sobre o ombro, o pescoço e as orelhas ornados com correntes de ouro ou grãos de coral; de resto, todas as modas da Europa burlescamente portadas por essas belezas de ébano, às quais os volants ${ }^{31}$ de gaze rosa e azul claros dão o mais esquisito aspecto. Muitas delas trazem cestos repletos de buquês de flores as mais magníficas. ${ }^{32}$

Bernard é uma autora tardia para os propósitos deste artigo, pois se estima que ela tenha passado poucos dias na Corte imperial já na segunda metade da década de 1850, publicando seu livro de viagem somente em 1864. Porém, a peculiaridade dos termos com que descreve as vestes das negras não pode deixar de ser citada. A menção ao "traje oriental da costa da África" não foi encontrada em nenhum outro viajante consultado: ou se vêem alusões às rou- 
pas dos 'escravos', 'africanos' e 'negros', ou a particularização dos critérios se dá mediante referências específicas às nações africanas. Além disso, ao contrário de Schlichthorst, Bernard ridiculariza a utilização de modelos destinados a senhoras brancas metidos em peles de 'ébano'.

Os viajantes vão, pois, delimitando e cristalizando uma série de concepções sobre os africanos na experiência da escravidão carioca, a começar por seus próprios corpos e os sinais que carregam. A segunda instância mais evidente deste esforço corresponde às expressões culturais. No interior deste tema, a música e a dança são, sem dúvida, as tópicas mais longa e detalhadamente acionadas pela literatura de viagem para ilustrar o estranhamento causado por algumas manifestações. Veremos, pois, um hiperbólico desfile de adjetivos utilizados nesses momentos.

\section{O “Teatro Etíope”}

Freireyss, um naturalista que gostava de teorizar manifestações artísticas ou lúdicas, formulou a seguinte explicação ao presenciar uma cena no Valongo:

Não há melhor nem mais certo padrão para o conhecimento de um povo do que as suas festas, os seus divertimentos ... Por isso, o negro selvagem, com a sua alegria barulhenta e o cômico meneio do seu corpo, indica o verdadeiro grau em que se acha na escala social, que, conforme as nossas idéias de beleza, está muito baixo, sendo singular que as danças dos negros sejam exatamente o contrário das nossas, porque ao passo que nós procuramos mostrar o nosso corpo na luz mais favorável e os nossos professores de dança se esforçam por dar aos seus discípulos uma posição exata e elegante, os negros procuram dar ao seu corpo as mais extravagantes posições, contrariando do modo mais desnatural possível o jogo de todos os seus músculos, e quanto mais ele o consegue maiores são os aplausos que lhe são dispensados. Basta entrar numa das espaçosas salas de um traficante na Capital, para ver uma porção de negros recém-chegados divertirem-se à moda do seu país, o que o traficante lhes permite, porque sabe que a falta de movimento e a nostalgia lhe diminuem o infame lucro. Encontramos aí alguns centos de negros nus e rapados, diversos tanto na idade como no sexo, que formavam uma grande roda, batendo palmas com toda a força, acompanhadas com os pés e com um canto gritado de três notas apenas.

Da roda sai de repente um deles, pula para o centro onde gira sobre si mesmo, movendo o corpo em todas as direções, parecendo destroncar suas articu- 
lações, e aponta para um outro qualquer, que por sua vez pula para dentro, fazendo o mesmo que o anterior e assim, sem mudança nenhuma, continuam até serem vencidos pelo cansaço. (Freireyss, cit., p.130)

É evidente o caráter jocoso que o viajante tencionou dar a esse registro, com a clara intenção de corroborar sua hipótese sobre o modo de se divertir e o grau de civilização de cada povo. Enquanto os europeus privilegiavam conceitos como exatidão e elegância de movimentos, os africanos demonstravam expressões nada 'naturais', exageradas e cômicas. Curioso é que Freireyss, ao contrário da grande maioria dos viajantes do período, afasta os negros de uma afinidade maior com a natureza em seus modos de agir. Bem mais comuns são os discursos que interpretam esses africanismos como indícios do primitivo, daquilo que se aproxima da natureza, justamente pelo fato de os negros serem considerados ainda nessa época, por meio de diversos prismas, mais próximos dos animais irracionais (mormente primatas) do que da espécie humana.

À semelhança das tatuagens e escarificações, a música e a dança também foram percebidas pelos viajantes como elemento pontuador de rivalidades entre grupos, para além do gosto comum de todos os africanos por essas atividades. Por ocasião da gravura "Escravos Doentes", Henry Chamberlain constrói um comentário que relaciona instrumentos musicais a nações específicas:

Absolutamente alheios ao que se está passando, prestando atenção somente à música, a que todos se entregam com a mesma paixão e fervor que às danças e aos enfeites, caminham dois outros negros. Um deles, filho de Moçambique, toca um instrumento tosco, trazido de sua terra natal, chamado marimba, espécie de violino com uma única corda. O outro, um negro do Congo, executa uma melodia diferente no sambee, um instrumento de seu país. Árias nativas são geralmente preferidas por eles a todas as outras, e quando estes instrumentos estão em mãos competentes, a música que produzem não é de modo algum desagradável. ${ }^{33}$

Assim, o militar inglês divide sua descrição em dois momentos nítidos, afirmando no primeiro o apreço generalizado pelos divertimentos musicais para, em seguida, distinguir — ainda que brevemente - especificidades de cada nação com relação a isso. Debret corrobora estas associações ao comentar que "o observador mais calmo reconhece logo, pelo caráter particular da dança e do canto, cada uma das nações negras que aí se encontram confundi- 
das”. Mais adiante, afirma que os negros "de nação mais bárbara” contentamse com "um bater de mão geral" mas que, ao contrário, "os negros benguelas, de Angola, devem ser citados como os mais musicais e são principalmente notáveis pelos instrumentos que fabricam" (Debret, cit., p.164). Ferdinand Denis também descreve as músicas e danças pelo viés das nações africanas, ainda que sem maiores especificações:

Não sei qual o viajante, é Golbery, creio, que disse que a certa hora da noite toda a África estava em dança, e que os negros dançavam mesmo no meio das sepulturas. Passando à América, suportando a dura lei da escravidão, os negros nada perderam de seu amor por seu exercício de predileção; conservam o uso de todos os instrumentos próprios de sua nação: a banza, o tambor congolês, o monocórdio de Loango soam continuamente nas ruas do Rio de Janeiro. Suas danças nacionais se improvisam em todos os lugares onde estejam seguros de que não serão interrompidos. $\mathrm{O}$ batuque, que alternativamente exprime as repulsas e os prazeres do amor; a capoeira, em que se finge o combate; o lundu, que mesmo no teatro se dança, e cuja graça consiste principalmente num movimento particular das partes inferiores do corpo ... todas essas danças apaixonantes que mil vezes têm sido descritas pelos viajantes, executam-se no Rio de Janeiro, como tinham tido lugar em nossas colônias e como se hão de executar em toda a parte onde houver negros, mudando somente de denominações. (Denis, cit., p.156-8)

Tendo feito várias estadas no Rio de Janeiro durante quinze anos, e familiarizado com as produções de viagem coevas, Denis deixa escapar que as danças africanas já haviam sido registradas ad nauseam por seus colegas de gênero literário. Mas, ao contrário da maioria deles, possui um olhar simpático a essas manifestações, classificando as danças como 'apaixonantes'.

Enquanto a narrativa do historiador francês deu mais espaço para as expressões corporais, Thomas Ewbank, na década de 1840, destacou o instrumento africano mais comum encontrado nos relatos de viagem:

Dia 25 - Esta manhã, um escravo chegou com uma carga na cabeça e levando nas mãos uma grande cabaça da qual extraía uma elegante melodia de valsa. Aproveitei a oportunidade para examinar a popular 'marimba'. Cada povo tem o seu instrumento nacional, de tal forma que é possível reconhecer o de Congo, o de Angola, o de Minas, ou de Moçambique, mas as diferenças não são grandes ... Segurando-a com os dedos por baixo e colocando os polegares nas chaves, o 
tocador de marimba, puxando-as para baixo numa ponta e em seguida deixando-as voltar, produz um suave som sussurrante, parecido com o de uma harpa hebraica. A cidade é um teatro etíope e esse o instrumento favorito da orquestra. Diariamente, se encontram escravos tirando dele árias africanas, e os grupos que voltam ao campo geralmente levam consigo uma ou duas marimbas. ${ }^{34}$

Reafirmando a percepção das diferenças de origem entre os instrumentos africanos, Ewbank faz uma crítica positiva dos sons emitidos pela marimba. E produz uma forte alegoria da afluência de africanos na Corte carioca: o "teatro etíope", figura de linguagem bastante eficiente para traduzir o espanto dos olhares europeus diante dos africanos, seus barulhos e gestuais.

Num tom diferente dos de Denis e Ewbank, a opinião de Johann Pohl aproxima-se mais daquela de Freireyss:

Os negros gostam muito de música. Consta da gritaria monótona de um entoador, cujo estribilho é seguido por todo o coro de maneira igualmente monótona, ou quando instrumental, do sonido de uma corda retesada num pequeno arco, num simples instrumento que descansa sobre uma cabaça esvaziada e dá, no máximo, três tons; ou do débil ruído de uma varinha de ferro fixada numa pequena tábua e que, ao contato com o polegar, deixa ouvir o seu pobre som. Aqui devo dizer uma palavra sobre suas danças. Consistem, como quase todas as danças propriamente nacionais, na expressão de galanteios. Apenas, num povo tão selvagem como o negro, o galanteio é grosseiramente indicado na dança. A nossa valsa, que repousa no mesmo princípio, e o próprio fandango, tão próximo de seu caráter primitivo, ficam muito atrás em expressão pantomímica, de uma dança angolana. Vêem-se com freqüência negros dançando nas ruas. Comumente são três, dos quais dois representam o par amoroso, cuja união o terceiro procura impedir. Deixam-se empolgar de tal maneira pelo furor báquico dessa dança, que não a interrompem enquanto não caem exaustos. (Pohl, cit., p.85-6)

Em consenso com seus pares, Pohl não se furtou à afirmação peremptória sobre gosto dos negros pela música. Em seguida, desqualifica a marimba e volta à carga ressaltando o caráter selvagem dos negros e, por conseguinte, de suas danças. Ao terminar seu registro evocando o adjetivo 'báquico', antônimo de 'apolíneo', Pohl denuncia uma das formas pelas quais era traduzida a oposição consolidada no século XVIII entre os costumes e maneiras que caracterizariam os povos civilizados (essencialmente os europeus, aqui qualificados em primeira pessoa do plural) e os selvagens. Em diapasão semelhante, 
a inglesa Maria Graham contou, por ocasião da visita a certa fazenda próxima do Rio de Janeiro:

Eu ouvi barulhos de música; não como, de fato, um eco de Milton com notas de Henry Lawe - com que a noite e o cenário tinham me feito sonhar; mas a voz dos escravos em sua noite de folga, consolando-se com suas árias grosseiras, tocadas em rudes instrumentos africanos. Levando um de meus companheiros comigo, fui imediatamente às cabanas dos escravos casados, onde são feitos todos os folguedos, e encontrei grupos tocando, cantando e dançando para o luar. Diz-se ser muito comum, na África selvagem, uma veneração supersticiosa por aquele belo planeta, como aquela pelas plêiades existia entre os índios do Brasil; e provavelmente os escravos, embora batizados, dancem para a lua em memória de seus lares. Por instrumentos, eles usam as coisas mais rudimentares que já produziram sons musicais; ainda assim não têm um efeito desagradável. ${ }^{35}$

É verdade que Graham produziu um testemunho mais condescendente do que o austríaco. Mas reforça, como a maioria dos relatos, o caráter grosseiro, primitivo e selvagem das demonstrações musicais africanas, no mais das vezes comparadas a exemplos europeus que corresponderiam a seus contrapontos. Debret também referenda o lugar bárbaro, quase demoníaco, dos cantos e danças africanas. A cena que constrói para tratar do tema inicia-se com a informação de que as "nações negras" se reúnem em torno dos chafarizes da cidade e que, quando um negro começa a cantar "pela saudade da mãe pátria", logo é seguido pelos demais. O pintor francês descarrega, então, uma série de termos para qualificar a natureza daquelas diversões: os negros lançam um "grito indeterminado" e o "canto que os eletriza se acompanha de uma pantomima improvisada ou variada sucessivamente pelos espectadores", transparecendo em seus rostos “o delírio de que estão possuídos” (Debret, cit., p.164). Em seguida, Debret mostra como geralmente acabavam tais reuniões:

Esses trovadores africanos, cuja facúndia é fértil em histórias de amor, terminam sempre suas ingênuas estrofes com algumas palavras lascivas acompanhadas de gestos análogos, meio infalível para fazer gritar de alegria todo o auditório negro, a cujos aplausos se juntam assobios, gritos agudos, contorções e pulos, mas cuja explosão é felizmente espontânea, pois logo fogem para todos os lados a fim de evitar a repressão dos soldados da polícia que os perseguem a pauladas. (Debret, cit., p.164-5) 
Selvageria, transe, rusticidade, exagerada sensualidade, exaltações e algazarra são, portanto, os elementos que compõem esse quadro emblemático, no qual Debret teve ainda a oportunidade de congratular a repressão policial que continha o temerário desgoverno dos negros. Nessa época, e no início do século XIX, esse tipo de juízo encontrado nas produções de viagem casava-se com formulações advindas da incipiente ciência antropológica. Em vários países da Europa, esse ramo do conhecimento estava se configurando a partir de uma preocupação essencial em formular idéias a respeito das diferentes "civilizações humanas" e o que caracterizaria cada uma delas, hierarquizando, além de características físicas, instâncias como a linguagem, ritos religiosos e festivos, modos, hábitos e manifestações artísticas de cada povo. No interior dessa ciência, os cantos e danças passaram a significar, pois, indícios inequívocos do grau inferior de civilização dos africanos. ${ }^{36}$

Vistos em conjunto, pois, esses fragmentos compõem tópicas que reiteram características inerentes aos africanos, do ponto de vista cultural e ou natural. A música e a dança correspondem a uma das mais incontestáveis e recorrentes expressões de africanismo entre as percepções dos viajantes. O lugar diferente e inferior dos africanos nessa literatura vai-se delimitando, assim, por meio de uma série de sinais que são visíveis primeiramente na forma de seus corpos, na anatomia e nas marcas de rostos e, ao lado disso, em seus atos de divertimento, rituais, linguagem, nos instrumentos, melodias e movimentos criados por mentes primitivas, guiadas por instintos peculiares e nada louváveis.

\section{CONCLUSÃO}

A partir da segunda metade do século XVIII, muitos pensadores europeus estavam interessados em estudar a diversidade os povos e suas relações com os lugares geográficos de onde provinham, construindo hierarquias ontológicas para a espécie humana, alocando os africanos no mais baixo degrau dessas escalas. Essas teorias científicas e estéticas, ao adentrarem o século XIX, sofreram releituras, reiterações e potencializações que, em poucas palavras, resultaram na legitimação do racismo científico em suas várias vertentes. ${ }^{37}$ No Rio de Janeiro, desembarcaram mais de uma centena de europeus informados direta ou indiretamente por esse cabedal intelectual.

Os viajantes que estiveram na cidade do Rio de Janeiro durante a primeira metade do século XIX expressaram sua estupefação com a enorme massa 
de escravos negros através de registros que comportavam constantes interlocuções, acabando por criar uma grande rede de tópicas textuais e imagéticas que passaram a circular no mercado editorial europeu. $\mathrm{O}$ que mais espantava e incomodava os visitantes era justamente o caráter africano daquela população. Os corpos apolíneos daqueles homens e mulheres, quase sempre contrastando com seus rostos horrendos e escarificados; seus cantos e danças bárbaros; sua 'índole' ou 'natureza' africana manifestando-se através de vários sinais e instâncias.

Todos esses elementos foram alvo de interpretação dos olhares europeus contidos no conjunto da literatura de viagem européia produzida ao longo da primeira metade do século XIX. Seus autores tinham formações e propósitos múltiplos. Eram naturalistas, historiadores, engenheiros, padres, pastores protestantes, médicos, pintores, literatos, cônsules, militares, oficiais navais, marinheiros, aventureiros. Escravistas, anti-escravistas, ou indiferentes a essa causa. A despeito de tantas diferenças, seus juízos a respeito dos africanos no Rio de Janeiro convergiram de forma notável. Vindos, pois, de distintos nichos profissionais e intelectuais, ainda assim foi possível perceber o quanto esses viajantes carregavam consigo uníssonas concepções inferiorizantes sobre os africanos, gestadas nos círculos acadêmicos europeus ainda nas últimas décadas do século XVIII.

\section{NOTAS}

${ }^{1}$ Este artigo é uma versão modificada de parte do terceiro capítulo de minha tese de doutorado em História Social, financiada pela Fapesp e orientada pela Prof ${ }^{a} \operatorname{Dr}^{a}$ Silvia Hunold Lara: Modos de ser em modos de ver: ciência e estética em registros de africanos por viajantes europeus (Rio de Janeiro, c.1808-1850). Campinas: Unicamp, 2006.

${ }^{2}$ KARASCH, Mary. A vida dos escravos no Rio de Janeiro. 1808-1850. São Paulo: Companhia das Letras, 2000, p.28.

${ }^{3}$ Para um bom apanhado dos mais conhecidos viajantes e suas obras sobre o Brasil da primeira metade do século XIX, ver, entre outros: LIMA, Valéria Alves Esteves. A viagem pitoresca e histórica de Debret: por uma nova leitura. Tese de doutorado. Campinas: Unicamp, 2003, p.181-201; POTELET, Jeanine. Le Brésil vu par les voyageurs et les marins français, 1816-1840. Paris: I'Harmattan, 1993; LISBOA, Karen Macknow. A Nova Atlântida de Spixe Martius: natureza e civilização na Viagem pelo Brasil (1817-1820). São Paulo: Hucitec, 1997, p.29-49; MARTINS, Luciana de Lima. O Rio de Janeiro dos viajantes. O olhar britânico (1800-1850). Rio de Janeiro: Zahar, 2001; e LEITE, Miriam L. Moreira. Livros de viagem: 1803-1900. Rio de Janeiro: Ed. UFRJ, 1997. 
${ }^{4}$ MATHISON, Gilbert Farquhar. Narrative of a visit to Brazil, Chile, Peru, and the Sandwich Islands, during the years 1821 and 1822. With a miscellaneous remarks on the past and present state, and political prospects of those countries. London: Charles Knight, 1825, p.12-3.

${ }^{5}$ DENIS, Ferdinand. Brasil. Belo Horizonte: Itatiaia; São Paulo: Ed. USP, 1980, p.124-5.

${ }^{6}$ John THORNTON oferece alguns elementos para essa discussão em Africa and Africans in the making of the Atlantic World (New York: Cambridge University Press, 1992). O estudo indica como a diversidade africana concebida pela Europa, no século XVII, não se diferenciou da visão oitocentista em muitos aspectos. Essa diversidade não teria passado despercebida aos olhos dos negociantes portugueses em contato direto com as populações africanas. Contudo, sua concepção de como estavam organizadas aquelas sociedades seguia critérios europeus para a definição de "povos". Desta forma, eram comuns referências portuguesas a "nações", normalmente definidas com base em unidades lingüísticas. O autor alerta que o termo "nação", na Europa do século XVII, mais do que político, era essencialmente lingüístico. Nicolau Parés complementa as observações de Thornton, enunciando um sentido mais amplo do vocábulo, forjado durante a prática do comércio negreiro na costa ocidental africana nos séculos XVII e XVIII: “Ao lado de outros nomes como país ou reino, o termo 'nação' era utilizado, naquele período, pelos traficantes de escravos, missionários e oficiais administrativos das feitorias européias da Costa da Mina, para designar os diversos grupos populacionais autóctones. O uso inicial do termo 'nação' pelos ingleses, franceses, holandeses e portugueses, no contexto da África ocidental, estava determinado pelo senso de identidade coletiva que prevalecia nos estados monárquicos europeus dessa época, e que se projetava em suas empresas comerciais e administrativas na Costa da Mina. Esses Estados soberanos europeus encontraram um forte e paralelo sentido de identidade coletiva nas sociedades da África ocidental. Essa identidade baseava-se, sobretudo, na afiliação por parentesco a certas chefias, normalmente organizadas em volta de instituições monárquicas”. (PARÉS, Luis Nicolau. A formação do candomblé. História e ritual da nação jeje na Bahia. Campinas: Ed. Unicamp, 2006, p.23). Nas primeiras décadas do século XIX o conceito de "raça", por sua vez, já havia consolidado significados que associavam uma origem geográfica a atributos físicos dos povos humanos. No dicionário da Academia Francesa de 1835, a primeira definição para "raça”, diferentemente do que se encontra nas edições setecentistas do mesmo compêndio, é: "uma multidão de homens que são originários do mesmo país, e se assemelham pelos traços do rosto, pela conformação exterior. A raça caucasiana, a raça mongólica, a raça malaia”. (Dictionnaire de L'Académie Française. Paris: Firmin Didot Frères, 1835, p.553). Os exemplos utilizados para ilustrar o vocábulo correspondem à divisão da espécie humana proposta pelo naturalista Johann Friedrich Blumenbach em 1795 (ver BINDMAN, David. Ape to Apollo. Aesthetics and the Idea of Race in the $18^{\text {th }}$ Century. New York: Cornell University Press, 2002, p.190-201).

${ }^{7}$ RUGENDAS, Johann Moritz. Viagem pitoresca através do Brasil. São Paulo: Martins, 1940, p. 70.

${ }^{8}$ D’ELVAS, Ramière. Beautés et merveilles de la nature au Brésil ou description pittoresque 
des productions, curiosités et phénomènes de cette contrée, des mouers et coutumes de ses habitans. Paris: Pierre Maumus, 1839, parte I, p.85. Trata-se de uma edição de bolso para estudantes, espécie de manual geográfico e histórico sobre o Brasil. A edição, pertencente à série "Librairie Enfantine et Juvénile", é uma coletânea de informações extraídas de outros viajantes, principalmente os que estiveram no Brasil entre 1815 e 1830: Henry Koster, James Henderson, Robert Walsh, John Luccock, Eschwege, Louis Freycinet, Spix e Martius e Auguste de Saint-Hilaire (o mais citado). Há uma hipótese de que Elvas seria apenas um pseudônimo de Ferdinand Denis, mas ao menos durante a pesquisa para a tese da qual se originou este artigo não foi possível comprová-la por meio de nenhum indício.

'SKOGMAN, Carl Johann Albert. Viaje de la Fragata Sueca "Eugenia" (1851-1853). Brasil — Uruguay - Argentina - Chile - Peru. Buenos Aires: Solar, 1942, p.22.

${ }^{10}$ WIED-NEUWIED, Maximilian de. Travels in Brazil in 1815, 1816 and 1817. London: Sir Richard Phillips and Co., 1820, p.9.

${ }^{11}$ ELLIS, Henry Ellis. Journal of the proceedings of the late embassy to China; comprising a correct narrative of the public transactions of the embassy, of the voyage to and from China, and of the journey from the mouth of the Pei-Ho to the return to Canton. London: John Murray, 1817, p.12.

${ }^{12}$ LAPLACE, Cyrille Pierre Théodore. Voyage autour du monde par les mers de l'Inde et de Chine exécuté sur la corvette de l'État La Favorite pendant les années 1830, 1831 et 1832. Paris: Imprimerie Royale, 1833, v.4, p.129-30.

${ }^{13}$ Ver SELA, Eneida Maria Mercadante. De Buffon a Saint-Sauveur: cores e formas da inferiorização. In: Modos de ser..., op. cit., p.15-100.

${ }^{14}$ REYNOLDS, Joshua, apud HONOUR, Hugh. The image of the Black in Western art. From the American Revolution to World War I. Houston: Menil Foundation, 1989, v.IV, p.10.

${ }^{15}$ Fugindo totalmente desta oposição, lembramos aqui os belos retratos a óleo feitos por Anne-Louis Girodet ("Portrait du Citoyen Belley", de 1797) e Marie-Guillemine Benoist ("Portrait d'une négresse", de 1800), ambos produzidos no contexto político francês pósSão Domingo e antes da restauração da escravidão nas colônias, em 1802. Os quadros representam indivíduos altivos e livres de qualquer símbolo de servidão ou depreciação, como plenos cidadãos. Para uma análise detida dessas obras e seus possíveis significados, ver, respectivamente: GRIGSBY, Darcy Grimaldo. Extremities: painting Empire in post-revolutionary France. New Haven \& London: Yale University Press, 2002, p.12-63; e HONOUR, Hugh. op. cit, p.7-11.

${ }^{16}$ LEITHOLD, Johanes Gottfried Theodor von; RANGO, Friedrich Ludwig. O Rio de Janeiro visto por dois prussianos em 1819. São Paulo: Cia. Ed. Nacional, 1966, p.33.

${ }^{17}$ Travels of his royal highness Prince Adalbert of Prussia, in the south of Europe and in Brazil, with a voyage up the Amazon and the Xingu. London: David Bogue, 1849, v.1, p.292.

${ }^{18}$ HENDERSON, James. A History of Brazil; comprising its geography, commerce, coloniza- 
tion, aboriginal inhabitants, \&c. \&c. \&c. London: Longman, Hurst, Rees, Orme and Brown, 1821, p.73-4.

${ }^{19}$ DEBRET, Jean-Baptiste. Viagem pitoresca e histórica ao Brasil. Belo Horizonte: Itatiaia; São Paulo: Edusp, 1989, v.2, p.80-1.

${ }^{20}$ Para uma discussão das teorias de Winckelmann ver, entre outros: POMIER, Édouard (Org.) Winckelmann: la naissance de l'histoire de l'art à l'époque des Lumières. Actes du cycle de conferences prononcées à l'Auditorium du Louvre du 11 decembre 1989 au 12 fevrier 1990. Paris: Documentation Française, 1991; POTTS, Alex. Flesh and the ideal: Winckelmann and the origins of art history. New Haven: Yale University Press, 1994; e MORRISON, Jeffrey. Winckelmann and the notion of aesthetics education. New York: Clarendon Press, 1996.

${ }^{21}$ EBEL, Ernst. O Rio de Janeiro e seus arredores em 1824. São Paulo: Cia. Ed. Nacional, 1972, p. 45.

${ }^{22}$ FREIREYSS, Georg Wilhelm. Viagem ao interior do Brasil. Belo Horizonte: Itatiaia; São Paulo: Edusp, 1982, p.126.

${ }^{23}$ BOSCHE, Eduard Theodor. Quadros alternados de viagens terrestres e maritimas, aventuras, acontecimentos politicos, descripções de usos e costumes de povos durante uma viagem ao Brasil, de 1824 a 1834. Rio de Janeiro: Imprensa Nacional, 1919, p.229.

${ }^{24}$ WALSH, Robert. Notices of Brazil in 1828 and 1829. London: F. Westleyand, 1830, v.1, p.130-1.

${ }^{25}$ SCHLICHTHORST, Carl. O Rio de Janeiro como é: 1824-1826 (huma vez e nunca mais). Contribuições dum diário para a história atual, os costumes e especialmente a situação da tropa estrangeira na capital do Brasil. Rio de Janeiro: Getúlio Costa, 1946, p.138-9.

${ }^{26}$ RUSCHENBERGER, William Samuel Waithman. Three years in the Pacific; including notices of Brazil, Chile, Bolivia, and Peru. Philadelphia: Carey, Lea \& Blanchard, 1834, p.29-30.

${ }^{27}$ RADIGUET, Maximilien René. Souvenirs de l'Amérique Espagnole. Études sur la société au Pérou et au Chili (la ville et la campagne de Rio de Janeiro). Paris: Michel Lévy Frères, 1856, p.261.

${ }^{28}$ OUSELEY, William. Travels in various countries of the East; more particulary Persia. London: Rodwell and Martin, 1819, v.1, p.15.

${ }^{29}$ Além de grandes conjuntos iconográficos oitocentistas mais conhecidos, como os de Debret, Rugendas, Thomas Ender e Joaquim Cândido Guillobel, uma boa amostra dessas indumentárias e acessórios pode ser encontrada em duas coletâneas: MOURA, Carlos Eugênio Marcondes de (Org.) A travessia da Calunga Grande. Três séculos de imagens sobre o negro no Brasil (1637-1899). São Paulo: Edusp, 2000; e ARAÚJO, Emanoel (Org.) Negro de corpo e alma. Catálogo da Mostra do Redescobrimento. São Paulo: Associação Brasil 500 anos Artes Visuais, 2000. 
${ }^{30}$ POHL, Johann Emmanuel. Viagem no interior do Brasil empreendida nos anos de 1817 a 1821. Rio de Janeiro: MEC-INL, 1951, v.1, p.85.

${ }^{31}$ Segundo a edição de 1835 do dicionário da Academia Francesa, uma das acepções do vocábulo é "o nome de uma guarnição que se amarra na parte inferior dos vestidos da mulher, e que se pode colocar ou tirar à vontade". (Dictionnaire de L'Académie Française, op. cit., p.952).

${ }^{32}$ BERNARD, Lina Beck Bernard. Le rio Parana. Cinq années de séjour dans la République Argentine. Paris: Grassart Libraire Éditeur, 1864, p.46-7.

${ }^{33}$ CHAMBERLAIN, Henry. Vistas e costumes da cidade e arredores do Rio de Janeiro. Rio de Janeiro: Kosmos, 1943, p.231.

${ }^{34}$ EWBANK, Thomas. Vida no Brasil ou Diário de uma Visita à Terra do Cacaueiro e da Palmeira. Belo Horizonte: Itatiaia; São Paulo: Edusp, 1976, p.91. Para uma descrição mais detalhada da marimba e de outros instrumentos musicais africanos confeccionados pelos escravos no Rio de Janeiro da primeira metade do século XIX, ver KARASCH, Mary, op. cit., p.315-21.

${ }^{35}$ GRAHAM, Maria. Journal of a voyage to Brazil, and residence there, during part of the years 1821, 1822, 1823. London: Longman \& Co., 1824, p.198-9.

${ }^{36}$ Além de músicas e danças, as línguas africanas também foram instrumento de inferiorização antropológica daqueles povos, a partir de idéias evidenciadas já no século XVIII. No artigo "língua" da enciclopédia de William Chambers, de 1728, consta que a "anatomia lingüística labial" de um inglês era oposta à conformação "gutural" dos hotentotes, o que proporcionaria uma dicção privilegiada aos primeiros. No tomo I da Histoire Générale des voyages do abade Prévost (1745), os habitantes ao sul do Cabo da Boa Esperança têm sua linguagem avaliada como "tão gutural e mal articulada", que ao fim das sete semanas em que os tripulantes de uma armada inglesa estiveram na região, não lhes foi possível "distinguir uma só sílaba”. Em suas Recherches philosophiques sur les américains... (1768), Cornelius de Pauw elaborou critérios para se classificar as comunicações verbais dos selvagens, como sua sonoridade, capacidade de expressar um sentido e se distinguir de ruídos emitidos por animais e, finalmente, a natureza desse sentido (valores morais, religiosos e estéticos). A partir desses elementos, de Pauw propôs duas grandes "cronologias lingüísticas": uma "longa", relativa aos "povos civilizados", e outra "curta", destinada às gentes "pouco desenvolvidas", ainda "na juventude de sua civilização". Assim, a língua dos selvagens americanos e de outros continentes eram consideradas incipientes, toscas e incapazes de exprimir seu passado e sua história. (ver MERCIER-FAIVRE, Anne-Marie. La danse du Hottentot: généalogie d'un desastre ou Kolbe réécrit par l'Encyclopédie, Prévost, Diderot et ce qui s'en suivit. In: MOUSSA, Sarga (Org.) L'idée de "race” dans les sciences humaines et la littérature (XVIII ${ }^{e}$-XIX ${ }^{e}$ siècles). Paris: L'Harmattan, 2003, p.75-7).

${ }^{37}$ Para um mapeamento e discussão dessas idéias, dentre as quais se destacam as do Conde de Buffon, Lineu, Kant, Herder, Lavater, Winckelmann, Blumenbach, Pieter Camper e 
Cuvier ver, entre outros: DUCHET, Michele. Anthropologie et Histoire au siècle des lumières. Paris: François Maspéro, 1971, p.229-473; CURTIN, Philip. The Image of África. British Ideas and Action, 1780-1850. Madison: The University of Wisconsin Press, 1973, v.1, p.3648 e 77-86; STOCKING Jr., George W. Race, Culture and Evolution. Essays in the History of Anthropology. New York: The Free Press, 1982, e The Idea of Civilization Before the Crystal Palace (1750-1850). In: Victorian Anthropology. New York: The Free Press, 1987, p.8-45; GOULD, Stephen Jay. O sorriso do flamingo: reflexões sobre História Natural. São Paulo: Martins Fontes, s.d.; GERBI, Antonello. O Novo Mundo: história de uma polêmica. 1750-1900. São Paulo: Companhia das Letras, 1996, p.19-76; EZE, Emmanuel Chukwudi. Race and the Enlightenment - a reader. Malden: Blackwell Publishers Inc., 1997; LINDFORS, Bernth (Org.) Africans on stage. Studies in ethnological show business. Bloomington: Indiana University Press, 1999; BINDMAN; David, op. cit.; ZAMMITO, John H. Kant, Herder, \& the Birth of Anthropology. Chicago: University of Chicago Press, 2002. 